\title{
DEPENDÊNCIA MOBILE: A RELAÇÃO DA NOVA GERAÇÃO COM OS GADGETS MÓVEIS DIGITAIS
}

\author{
Mobile dependence: the relation of the new generation with \\ digital mobile gadgets
}

\section{La dependencia móvil: la relación de la nueva generación con los dispositivos móviles digitales}

\author{
Priscila Valim Carneiro Vidal \\ Graduação em publicidade pela Faculdade de Comunicação da Universidade de Brasília
}

\author{
Edmundo Brandão Dantas \\ Professor pesquisador do Programa de Pós-Graduação em Comunicação da Faculdade de Comunicação da \\ Universidade de Brasília \\ E-mail: edmundod@terra.com.br
}

\begin{abstract}
RESUMO O artigo aborda a relação das gerações Z e Y com os dispositivos móveis digitais, sintetizando as descobertas verificadas a partir de estudo exploratório e descritivo realizado sobre a interação de ambas com o smartphone. A intenção do estudo foi verificar se a geração Z apresenta maior grau de dependência a esses dispositivos do que a geração Y. Além de pesquisa bibliográfica e documental, foi realizada pesquisa de campo, com aplicação de questionários no Distrito Federal, com abordagem quantitativa e qualitativa, bem como é apresentada a análise de relatos de dois indivíduos pertencentes à geração Z que foram impedidos de utilizar seus celulares por um período. O resultado sugere que há maior dependência da geração Z, embora a diferença não seja tão expressiva.
\end{abstract}

PALAVRAS-CHAVE Comunicação, Mídia móvel, Smartphone, Geração Z, Geração Y.

\begin{abstract}
This article covers the relationship between $Z$ and $Y$ Generations with the digital mobile gadgets, synthesizing the findings verified from an exploratory and descriptive study carried about the interactions of both of them with the smartphones. The intent of the study was to verify if the $Z$ Generation should have a higher rate of dependence on those gadgets compared with the $Y$ Generation. In addition to a bibliographical and documental investigation, it was carried a field survey, applied in the Federal District, with both quantitative and qualitative approach and application of questionnaires, as well as the analysis of two reports of individuals belonging to the $\mathbf{Z}$ Generation who were restrained to use their cell phones within a period. The result suggests that the $Z$ Generation is more dependent concerning the digital mobile gadgets, although this degree of difference is not excessively different from the dependency observed in the Z Generation.
\end{abstract}

KEYWORDS Communication, mobile media, smartphone, Z Generation, Y Generation.

RESUMEN El articulo aborda la relación de las Generaciones X y Y con los dispositivos móviles digitales, sintetizando los descubrimientos verificados a partir de estudio exploratorio y descriptivo realizado acerca de la interacción de ambas con el smartphone. La intención del estudio fue verificar si la Generación Z presenta mayor grado de dependencia a eses dispositivos comparada a la Generación Y. Además de una investigación bibliográfica y documental, se realizó una investigación de campo, aplicada en el Distrito Federal, con enfoque cuantitativo y cualitativo y aplicación de cuestionarios, así como el análisis de dos relatos de individuos pertenecientes a la Generación Z que fueron impedidos de utilizar sus teléfonos celulares por un período. El resultado sugiere que hay una mayor dependencia de la Generación Z con respecto a los dispositivos móviles digitales, aunque esa diferencia no se presente en grado excesivamente diferente de la dependencia observada en la Generación Y.

PALABRAS CLAVE Comunicación, Media móvil, Smartphone, Generación Z, Generación Y. 


\section{INTRODUÇÃO}

O desenvolvimento de novas tecnologias nas últimas décadas tem alterado a forma de o ser humano ver e se relacionar com o mundo. Hoje se fala de uma geração nativa digital, nascida nos meados dos anos 1990, que compreende muitas dessas novas descobertas como essenciais e cotidianas. Para os mais jovens, a tecnologia aparenta ser como o ar: essencial, porém invisível (Tapscott, 2010).

$\mathrm{Na}$ nova configuração apresentada pelo mundo digital, o que conhecemos por mundo real e mundo virtual se entrelaça, e os dois mundos passam a ser vividos simultaneamente. Não cabe, porém, chamar nosso mundo material de real em oposição ao virtual, como explica Lévy (2010, p. 549), para quem "é virtual toda entidade 'desterritorializada', capaz de gerar diversas manifestações concretas em diferentes momentos e locais determinados, sem contudo estar ela mesma presa a um lugar ou tempo em particular”. Lévy usa como exemplo a palavra, que não existe em um só lugar, e sim onde quer que seja utilizada, sendo portanto virtual, mas nem por isso irreal. Assim, "ainda que não possamos fixá-lo em nenhuma coordenada espaçotemporal, o virtual é real. Uma palavra existe de fato. O virtual existe sem estar presente" (Idem, p. 50).

Santaella (2009, p. 126) utiliza os conceitos de "corpos carnais” para os corpos off-line, e "corpos alternativos”, para as representações em meio digital:

[...] abandonei a denominação de "corpos reais" e "corpos virtuais", preferindo chamar de "corpos carnais" e "corpos alternativos”, pois não há oposição epistemológica mais equivocada do que aquela que opõe o virtual ao real ou o virtual ao físico, como se as representações virtuais não fossem também físicas e reais. A diferença não está em ser real ou não real, mas nos tipos de realidade e de fisicalidade que são distintas nesses casos. Veio daí minha predileção pelo "carnal", pois este adjetivo explicita de que tipo de matéria física e mental se trata aí.

Utilizando-nos dos conceitos, poderíamos falar de um mundo alternativo em meio digital como representação do mundo carnal. Esses mundos tornam-se cada vez mais permeados entre si, resultando em um quadro onde a conexão ininterrupta torna-se vital, valorizando-se, então, os dispositivos móveis digitais, principalmente os que oferecem acesso contínuo à rede.

Nesse novo cenário de conexão dinâmica e contínua, os telefones móveis celulares tendem a estar por perto em grande parte do tempo. Recorre-se a eles frequentemente para os mais variados fins. Conforme dados da Agência Nacional de Telecomunicações (Anatel), em setembro de 2014 o Brasil tinha aproximadamente 278,5 milhões de celulares, com uma média de 137,1 celulares/100 habitantes (Teleco, s/d). Os smartphones - celulares com funcionalidades avançadas, estendidas por meio de programas executados por seu sistema operacional são os gadgets ${ }^{1}$ com maior crescimento nos últimos anos. Sua venda cresceu $28,7 \%$ no $1^{\circ}$ trimestre de 2014 , comparado ao mesmo período

1. Do inglês: geringonça, dispositivo. Refere-se a um equipamento que tem um propósito e uma função específica, prática e útil no cotidiano. 
de 2013, segundo a International Data Corporation (IDC) (Teleco). Com eles, é possível se conectar a outras pessoas por meio de SMS ${ }^{2}$, ligações e Internet, jogar, pesquisar, acessar a rede, anotar lembretes, organizar agendas, programar o despertador, entre várias funções proporcionadas pelos aplicativos, que se avolumam cada dia mais.

Surgiram os conceitos de gerações, classificadas conforme o período em que as pessoas nasceram, aliando-se hábitos comportamentais, marcos históricos e sociais e, mais recentemente, o uso das novas tecnologias que associam telecomunicações e informática. Foram cunhadas as expressões "baby boomers", formada por indivíduos nascidos entre 1948 e 1963, "geração X” (entre 1964 e 1977), "geração Y” (entre 1978 e 1994) (Engelmann, 2009) e "geração Z” (entre 1995 e 2010) (Malafaia, 2011). A geração $Z$ já nasceu em um mundo digitalizado e leva o nome a partir da palavra "zapear"3, uma das características marcantes de seus componentes: não costumam focar apenas um objeto por longos períodos e tendem a realizar mais de uma tarefa ao mesmo tempo. Por serem nativos digitais, têm familiaridade muito maior com as novas tecnologias, porém parecem ter menor capacidade de solucionar problemas sem elas.

O crescimento e o uso frequentes das novas mídias intrigam sobre a possível relação entre os gadgets e seus usuários e uma possível maior dependência entre adolescentes do que entre jovens. A pesquisa levantou dados sobre a questão e verificou o fim buscado por cada geração no uso cotidiano dessas mídias.

A partir da diferença no uso e na significação das novas tecnologias pela geração Z, perceptíveis sob rápida observação, surgiu o problema de pesquisa: estabeleceria a geração $\mathrm{Z}$ maior relação de dependência com as mídias móveis digitais do que a geração Y?

Para tentar solucionar o problema, definiu-se como objetivo geral investigar como os componentes de ambas as gerações se comportam em relação à dependência de smartphones, e, como objetivos específicos, identificar as funcionalidades dos telefones móveis mais utilizadas por adolescentes e jovens; verificar como adolescentes e jovens reagem à ausência do aparelho; investigar o ciberespaço com as mídias móveis; analisar a significação de tais mídias para as gerações pesquisadas; investigar o papel dos smartphones no cotidiano das gerações pesquisadas; e verificar o tempo empregado no uso dos telefones móveis pelas gerações Y e Z.

\section{METODOLOGIA}

Iniciou-se estudo exploratório de cunho bibliográfico e documental, a partir de autores que relatavam a relação das novas gerações com o ciberespaço e as novas mídias, "a fim de comparar usos e costumes, tendências, diferenças etc.” (Santaella, 2001, p. 145) e de verificar possíveis tendências no consumo dos smartphones pelas gerações $\mathrm{Y}$ e Z .

Em seguida, observou-se o objeto do estudo, suas relações e implicações sob um olhar crítico, emprestando ao estudo caráter

2. Short message service (SMS): mensagem de texto enviada a partir de celulares.

3. Da expressão inglesa zapping, que é o ato de trocar de canais por meio do controle remoto.

É usada para se referir à troca constante de “canais”, sem se prender a um só foco. 
descritivo, visto que em parte foi realizado a partir de observação, descrição e análise do fenômeno pesquisado, sem que houvesse intervenção (Idem).

Para análise do objeto de estudo, foi realizada pesquisa qualiquantitativa com aplicação de questionários e realização de relatos de dois indivíduos da geração $\mathrm{Z}$, privados temporariamente de seus smartphones, sobre suas sensações. A pesquisa quantitativa possibilitou o levantamento e a análise de números sobre o assunto, sendo complementada por pesquisa qualitativa, visto que o fenômeno é subjetivo e significativo.

O pré-teste do questionário, realizado com cinco pessoas por meio do Google Docs, evidenciou a necessidade de ajustes na formulação das perguntas para corrigir ambiguidades e problemas quanto à forma. Foi corrigido e formulado novo questionário no Survey Monkeys, com 13 perguntas, aberto para preenchimento no dia 2 de outubro de 2014, por meio de link para a página e distribuído por WhatsApp. Em 7 de outubro, abriu-se link por meio de um post no Facebook, compartilhado 19 vezes. Os links ficaram abertos até o dia 18 de outubro. Foram obtidas 343 respostas, de pessoas entre 66 e 14 anos, sendo 262 via link e 81 via post.

O resultado obtido evidenciou grau de confiança de $90 \%$ e margem de erro de $\pm 5 \%$, estatísticas consideradas satisfatórias para validação da pesquisa realizada.

\section{FUNDAMENTAÇÃO TEÓRICA}

Em 1964, quando McLuhan falava em meios quentes e frios de comunicação, o telefone, inventado em 1870, e o telégrafo, cujo boom ocorreu em 1910, já traziam em si muito do poder das mídias atuais em atuar na intimidade e possibilitavam a ressignificação por quem os utilizasse: a comunicação em tempo real e a distância ultrapassou fronteiras (Lemos, 2013).

A partir dessa ambição histórica do homem, percebe-se que a Internet, tempos depois, além de trazer novidades, potencializou desejos e possibilidades trazidos pelos meios de comunicação dos séculos anteriores ao convergir com muitos desses meios, indo além dos computadores e alcançando novas significações. A invenção do rádio e do tubo iconoscópico e a transformação de informações em sinais elétricos, por exemplo, possibilitaram o desenvolvimento de novas mídias e, consequentemente, de novas formas de se comunicar. Cabe esclarecer, entretanto, que a Internet não determina as alterações comportamentais e culturais, e sim as condiciona. Isso "significa dizer que abre algumas possibilidades, que algumas opções culturais ou sociais não poderiam ser pensadas a sério sem sua presença” (Lévy, 2010, p. 25). A televisão surgiu graças a pesquisas sobre o tubo iconoscópico, mas suas implicações não têm relação direta de causa e efeito com a técnica. A cultura gerada após o advento de uma mídia não pode ser reduzida a um produto da técnica, visto que a técnica em si já é um produto da cultura, como alerta Lévy (2010).

Experimentamos várias inovações que respondem aos nossos anseios e desejos, possibilitadas ou condicionadas pelas novas tecnologias e técnicas desenvolvidas a cada dia. A cibercultura surge como produto de um alinhamento dos valores da época a um desenvolvimento tecnológico. 
Inicialmente, novidades na informática condicionaram o surgimento do ciberespaço, um espaço desterritorializado que acompanha, traduz e favorece uma evolução da civilização (Idem), e que é visto por alguns autores como uma realidade virtual que permite ao usuário da Internet imergir nele por meio de simulações em três dimensões e estímulos sensoriais. Os computadores deixam de acessar dados limitados a sua materialidade para se transformarem em portas para informações espalhadas por todo o mundo.

Para a maioria dos estudiosos, a realidade virtual seria apenas um grande espaço informacional potencialmente interativo (Santaella, 2004), e o ciberespaço constituiria um universo virtual paralelo ao nosso físico, carnal. Os computadores e, depois, os diversos dispositivos, cada vez mais portáteis, serviriam como geradores e janelas para acessar esse outro mundo em que "os objetos vistos e ouvidos não são nem físicos nem, necessariamente, representações de objetos físicos, mas têm a forma, caráter e ação de dados, informação pura” (Idem, p. 40).

A Internet, no início, não era a tecnologia acessível de hoje. O ideal moderno tinha a rede como centralizada e relacionada a pesquisas militares. A troca de informações tinha finalidades específicas, e a imersão no ciberespaço restringia-se a certos profissionais. A convergência do ciberespaço com aparelhos celulares redefine a utilização dos telefones móveis e nossa forma de nos relacionarmos com eles, assim como redefine o próprio ciberespaço:

Além dos intensos deslocamentos internos que são próprios dos fluxos informacionais do ciberespaço, passam a existir deslocamentos externos, acompanhando os movimentos dos usuários, ou seja, o ciberespaço ganha o trânsito das ruas e os usuários conectam-se a vários espaços simultaneamente como mínimo de deslocamento físico. (Santaella, 2009, p. 133)

O acesso à rede passa a ser cada vez mais móvel e contínuo: estamos conectados todo o tempo e em todo lugar. A possibilidade de instalar ou desinstalar aplicativos nos smartphones torna-os quase totalmente personalizáveis, conforme nossas preferências, e, por oferecerem programas para variadas tarefas, ocupam espaço maior no dia a dia.

Há aplicativos para auxiliar a acordar, contar os metros de caminhada, organizar compromissos de trabalho, monitorar residências, lembrar datas comemorativas, comunicar-se com outras pessoas, indicar receitas novas e até monitorar o sono. Os smartphones tornam-se essenciais no cotidiano: "Vamos ter de chamá-los de outra coisa - amigo ou co-piloto digital -, porque todos nós, jovens e velhos, vamos depender expressivamente deles para chegar ao fim do dia" (Tapscott, 2010, p. 63).

Essas mudanças alteram também a forma como interagimos com os aparelhos móveis. Apesar de serem meios quentes desde sua origem, segundo Lemos (2013, p. 112), eles deixam de ter somente uma interação social para ter uma interação eletrônico-digital: antes interagíamos com o objeto, mas "a tecnologia digital possibilita ao usuário interagir, não mais apenas com o objeto (a máquina ou a ferramenta), mas com a informação, isto é, com o conteúdo".

Inovações continuam em ritmo acelerado. A cada nova linha de smartphones, novas funções surgem, tornando o uso mais simples, orgânico e inteligente, enquanto o acesso ao virtual se expande. 
Contemplamos um mundo de pessoas e objetos cada vez mais interconectados. Podemos "estar" em qualquer lugar, a qualquer momento, com qualquer companhia, a ponto de essa experiência offline ser confundida com o mundo off-line. Os dispositivos de acesso podem nos acompanhar onde quer que estejamos: "a diversificação e a simplificação das interfaces, combinadas com os progressos da digitalização, convergem para uma extensão e uma multiplicação dos pontos de entrada no ciberespaço" (Lévy, 2010, p. 39). A multiplicidade de entradas para o ciberespaço nos possibilita estar mais tempo conectados à rede, porquanto não é necessário ficarmos "presos” a um ponto fixo para a imersão:

Até recentemente, era necessário que se sentasse em frente a uma tela de computador para entrar no espaço virtual. Isso significa que a passagem através da janela de vidro era deliberada e limitada pelo tempo que você poderia gastar em frente a um computador. Agora, com os dispositivos móveis como portal, é possível imergir no mundo virtual de forma fluída e em movimento. (Turkle, 2011, p. 160)

A facilidade e a fluidez da comunicação mobile facilitam também a simultaneidade das vidas on-line e off-line, criando o que Sherry Turkle chama de mix de vidas. Ela cita o caso de um homem casado que tem outra esposa no Second Life e relata que essa vida virtual é parte de sua vida real. Esse mix de vidas, porém, pode ser alcançado não somente quando pensamos em mundos virtuais, como o Second Life, mas também nas redes sociais, em que cada ingressante pode criar um perfil cujo papel é apresentar sua identidade: quem é, o que gosta de fazer, onde trabalha, quem são seus amigos etc. Entretanto, os perfis das redes sociais não refletem a vida em sua totalidade. Pode-se escolher 0 que se quer mostrar (e sob que ângulo) e o que se quer omitir. Podese reconstruir para criar uma espécie de avatar do seu melhor lado na web, ou personificar o que gostaria de ser. Quanto à construção da identidade virtual, Turkle (2011, p. 180) afirma que:

[...] esse tipo de trabalho de identidade pode tomar lugar onde quer que se crie um avatar. E isso pode tomar lugar em redes sociais, onde o perfil de alguém se torna uma forma de avatar, uma declaração não somente sobre quem você é, mas quem você quer ser.

A simultaneidade das vidas torna a vida virtual em uma parte da vida off-line, e não algo oposto e desvinculado. Quando pensamos nas redes sociais ou nos aplicativos ligados à rede de comunicação imediata, verificamos que muito do que é vivido no mundo off-line precisa de uma validação na vida on-line para que a experiência se torne completa. Para muitos, não basta viajar, é preciso postar fotos na rede; não basta se sentir triste ou feliz, é preciso compartilhar com todos os seus amigos. Para Turkle (2011, p. 177), "a tecnologia não causa, mas encoraja uma sensibilidade em que a validação de um sentimento se torna parte de estabelecê-lo, ou até mesmo parte de senti-lo”.

A partir dessas necessidades e possibilidades, os dispositivos móveis vão, cada vez mais, agregando novas funções, inclusive de outras mídias. Celulares, hoje, possuem câmera fotográfica, acessam a rede, fazem ligações, enviam mensagens, dispõem de rádio AM/FM e possibilitam que se assista a televisão digital, por meio de uma pequena antena acoplada. As mídias caminham cada vez mais para uma união em um só aparato. 
Aparatos e tecnologias surgem visando facilitar tarefas, maximizar o tempo, garantir maior eficiência e possibilitar maior prazer: afinal, "a tecnologia é sedutora, à medida que o que propõe vai de encontro às vulnerabilidades do homem” (Idem, p. 1). Assim, procuramos as novidades que nos aperfeiçoem e maximizem.

Porém, ao mesmo tempo que nos dão vantagens em atividades e no cotidiano, os aparatos digitais nos transformam em um ser humano novo, com uma nova forma de entender a si mesmo e de se relacionar com o mundo:

Conectados à rede através de nossos dispositivos móveis, nós alcançamos um novo estado do "eu”, o "eu-objeto" ("itself"). Para iniciar, ele supõe certos direitos: ele pode se ausentar de ambiente físico ao seu redor - incluindo as pessoas nele. Ele pode experimentar o físico e o virtual em simultaneidade. E ele pode criar mais tempo através da multitarefa, ou nossa alquimia do século XXI. (Idem, p. 155)

Verificando mais a fundo essas implicações no novo "eu", encontramos a dependência que parece caracterizar gerações mais novas e tecnologias, por vivenciarem esse novo estilo de vida desde a infância. O homem atual fica mais tempo sozinho (não está fisicamente na presença de outras pessoas), mas, ao mesmo tempo, ao imergir no ciberespaço, busca nunca estar só, através da conexão com outras pessoas. Vive, então, nesse paradoxo da solidão: para estar junto dos colegas na rede, quanto menores forem as interrupções em sua conexão, melhor; para ser menos interrompido, quanto mais sozinho estiver, melhor; e quanto menos contato pessoal tem, mais sozinho se sente, visto que os relacionamentos on-line não o suprem. É um jogo dinâmico e paradoxal entre o sozinho e o junto, que, quando se está junto, se está sozinho, e quando se está sozinho, se está junto (Idem).

Lemos (2013, p. 73) explica essa falta de contato em meio a tanto contato valendo-se de Baudrillard, cujo pensamento é "aquele do excesso: quanto mais trocamos informações, menos estamos em comunicação. Trocamos o real pelo hiper-real, a verdadeira comunicação por sua simulação".

A busca por momentos sozinhos não é novidade. O homem moderno também buscava seus momentos sozinho, mas há diferenças na forma de solidão. O homem atual é ausente mesmo quando presente, pois ausenta seu "eu" do mundo físico, ainda que seu corpo carnal esteja lá, por meio da imersão no ciberespaço, mas experimenta, também, ficar verdadeiramente só, com momentos de introspecção e descoberta de si mesmo como indivíduo em meio ao mundo, como explica Sibilia (2008, p. 104):

Na solidão do quarto próprio - ou, para os menos afortunados e afortunadas, onde quer que encontrassem a tão prezada solidão -, o sujeito moderno podia mergulhar na própria opacidade interior, a fim de delinear no papel os resultados de tais sondagens e, assim, criar-se.

O homem pós-moderno, quando ausente fisicamente de companhias, dificilmente se encontra sem nenhuma conexão, descobrindo-se, portanto, como pessoa on-line. Ele se constrói no mundo virtual. Não estar conectado à rede significa não estar conectado a si mesmo: uma 
parte de si se perde. Com o uso dos dispositivos móveis digitais, o acesso à rede torna-se ainda mais simplificado, permitindo que o mundo alternativo permeie cada vez mais o mundo carnal. Passamos a viver nos dois mundos simultaneamente; o corpo alternativo, representação do corpo carnal, e o corpo carnal em si passam a se fundir em um novo eu (Santaella, 2009).

Passamos, portanto, a viver um mix de vidas em que não caberiam mais divisões e limitações; todas se resumem em um só produto final, todas são vida. Da mesma forma, nossas representações na web, nossos corpos alternativos, fazem parte de quem somos. O tempo que os mais jovens passam na vida alternativa, ou seja, a conjunção do mundo alternativo com os corpos alternativos, pode torná-la mais significativa para a construção da personalidade do que a vida no mundo carnal. Como lembra Turkle (2011, p. 153), "quando parte da sua vida é vivida em ambientes virtuais - podendo ser Second Life, um jogo de computador, um site de rede social - um relacionamento controverso se desenvolve entre o que é verdade e o que é 'verdade aqui', na simulação".

Sibilia (2008) explica essa reconstrução do eu às vistas da subjetividade. Se antes o sujeito buscava dentro de si a essência do "eu", em torno da alma ou da psique, o eixo se desloca, e o "eu" passa a se estruturar em torno do corpo. Alinhado ao mundo da cibercultura, esse novo sujeito passa a ver necessidade de aparecer para construir sua identidade.

Como os mundos alternativo e carnal são simultâneos, não é necessário que os jovens deixem suas casas para aparecer, pois podem estar presentes on-line e afirmar sua existência em um ambiente que possibilita reconstrução e edição, mostrando o que querem que seja entendido como seu "eu".

Além da simultaneidade de mundos, os dispositivos móveis possibilitam outra forma de simultaneidade: a de tarefas. Segundo Turkle (2011, p. 164):

Nossos dispositivos conectados encorajam uma nova noção de tempo, pois prometem que podemos sobrepor outras atividades a ele. Porque podemos enviar mensagens de texto enquanto fazemos algo a mais, enviar mensagens não parece tomar tempo, mas ganhar tempo. Isso é mais do que bem-vindo; é mágico.

Uma das características das gerações $\mathrm{Y}$ e Z é essa capacidade. Tapscott (2010, p. 56) afirma que "a realização simultânea de tarefas é natural para essas gerações. Enquanto estão on-line, 53\% ouvem MP3, $40 \%$ falam ao telefone, $39 \%$ assistem à televisão e $24 \%$ fazem o dever de casa”.

Estudiosos chegaram a declarar que a capacidade de ser multitarefa seria essencial para trabalhar e estudar com sucesso na cultura digital, porém o que parece ser uma virtude sob um primeiro olhar revela problemas após uma análise mais demorada:

Quando psicólogos estudam a multitarefa, eles não acham histórias de novas eficiências. Ao contrário, pessoas multitarefas não desenvolvem tão bem qualquer trabalho que estejam realizando. Mas realizar tarefas simultâneas parece bom porque o corpo recompensa isso com neurotransmissores que induzem um "barato". Esse barato engana os multitarefas, fazendo-os pensar que eles estão sendo 
especialmente produtivos. Na procura desse barato, eles querem fazer cada vez mais. Nos próximos anos haverá muita coisa para se resolver. Nós nos apaixonamos pelas facilidades da tecnologia. Nossos corpos foram coniventes. (Turkle, 2011, p. 163)

Buscaríamos ser cada vez mais multitarefas, embora a prática não ajude na produtividade e não ajude a ganhar tempo. Turkle resume (2011, p. 166): "Insistimos que nosso mundo é cada vez mais complexo, porém criamos uma cultura de comunicação que diminui o tempo disponível para sentarmos e pensarmos ininterruptamente”.

Com as novas configurações do humano possibilitadas pelas novas tecnologias surge o termo "ciborgue" (Clynes; Kline, 1960), referindo-se ao conceito de "homem ampliado", um homem adaptado por drogas e tecnologias (Santaella, 2007).

Apesar de parecer algo futurístico e artificial, Santaella e Lemos concordam que essa aparente evolução artificial seria natural do humano. Santaella (2007) defende que as tecnologias, como as máquinas para a produção técnica de imagens, sons, audiovisuais e, atualmente, hipermídia, junto com os avanços das simulações computacionais na realidade virtual, robótica e vida artificial, não nos são tão estranhas quanto parecem ser. Lemos (2013, p. 179) destaca que "o artificial, longe do que imaginamos no senso comum, é profundamente humano" e que "a dicotomia entre o artificial e o natural perde sentido e a questão do cyborg pode ser colocada como estrutural da própria humanidade e como característica inegável da cibercultura”.

Lemos (2013) divide os ciborgues em três grupos: os protéticos, que "simbolizam a simbiose entre o orgânico e o inorgânico, mais especificamente entre as nanotecnologias cibereletrônicas e o corpo" (p. 185); o interpretativo, que "se constitui pela influência dos mass media, coagido que é pelo poder da televisão ou do cinema” (p. 187); e os netcyborgs, ou seja, os ciborgues interpretativos das redes, que ganham potencialidades emancipatórias pela estrutura do ciberespaço. Alerta ainda que, "para o netcyborg do planetário corpo-rede, que é o ciberespaço, o corpo é um grande simbiótico com o ambiente digital das redes eletrônicas” (p. 188).

Embora a ideia de ciborgues ainda pareça distante, Turkle (2011) aproxima o termo do nosso cotidiano ao relatar o que vivenciou no Massachusetts Institute of Technology, quando conheceu pessoas que viviam como ciborgues, equipando-se com "parafernálias tecnológicas", que se tornam membros adicionais de seus corpos, e experimentando viver no físico e no virtual simultaneamente. O que parecia muito excêntrico na época acaba se tornando parte da realidade de todos.

Nosso corpo passa, então, por essa reconstrução: em parte carnal, em parte representativa. Experimentamos uma nova forma de ser livres - com um universo de possibilidades - e, ao mesmo tempo, presos - necessitando estar todo o tempo conectados à rede para alcançá-las.

A nova ressignificação do corpo a partir da simbiose com a tecnologia já resultou em alterações que são tratadas como distúrbios de saúde de ordem psicológica e neural. Nas últimas décadas perceberam-se a síndrome do membro fantasma e a nomofobia, fenômenos recentes, pouco estudados academicamente, com poucas publicações formais. A síndrome do membro fantasma seria um distúrbio da ordem da alucinação tátil, e não uma síndrome tecnicamente: o indivíduo sente o celular vibrando, mesmo quando não há vibração. Ela ainda 
não foi estudada a ponto de sua causa ser comprovada, mas já foram levantadas hipóteses por estudiosos da medicina: uma seria a de que o cérebro passa a entender o celular como parte do corpo humano e reage à ausência de vibração do celular da mesma forma que reage a membros amputados (Williams, 2007); outra seria a da vibração ser uma interpretação errônea do córtex cerebral de sinais nervosos recebidos por antecipar uma vibração esperada (Rothberg et al., 2010). Ambas partem do princípio de uma relação próxima, seja entendendo o aparato como parte do corpo, seja antecipando um estímulo frequente. A alucinação mostra o extremo, a colonização tratada por Lemos (2013, p.177), quando afirma que "a profusão de equipamentos baseados no principio da informação, da comunicação e da miniaturização nos revela, em todos os momentos da vida quotidiana, a tecnologia onipresente, chegando a colonizar nossos corpos”.

Já a nomofobia é o medo de permanecer sem conexão móvel, ainda não reconhecida por todos os estudiosos. Por ser fenômeno recente, definir um comportamento aditivo não é tarefa fácil. Alguns autores defendem a existência de dependência a serviços específicos como jogos ou SMS (Abreu; Costa; Góes, 2013, p. 107). Em pesquisa realizada em 2008 pelo Instituto Ipsos, 18\% dos entrevistados reportam ser viciados em seus aparelhos celulares (Idem, p. 107), o que indica a relevância do tema.

A geração baby boomer é fruto do grande aumento da natalidade nos Estados Unidos, causada pelo fim da guerra, sendo bebês com boas condições econômicas e perspectivas futuras. Apesar desses índices não serem comuns em todo o mundo, essa geração não se restringe aos EUA, visto que, junto com a cultura pop, são exportados também costumes. Dessa forma, no Brasil, muito influenciado pela cultura dos EUA, pode-se falar nessa geração, marcada por grandes mudanças sociais e econômicas, e que tem na televisão um marco e um definidor. Segundo Tapscott (2010, p. 23), "foi o impacto da revolução nas comunicações liderada pela ascensão da televisão - que moldou essa geração mais do que qualquer outra coisa”. A televisão torna-se uma janela para outro mundo em tempo real, e despende-se muito tempo em frente a ela. Famílias se reúnem para assistir, enquanto o diálogo entre os fraternos é substituído pelo monólogo da televisão.

A geração X, como a geração baby boomer, também tem forte relação com a televisão. Nascida quando essa mídia já está consolidada e num ambiente em que os pais priorizam o trabalho, resta à criança a companhia da televisão. A geração Y, ou geração Internet (Tapscott, 2010), nasce em meio à consolidação da Internet, e tem contato muito cedo com a imersão no ciberespaço. Para seus componentes, não há espanto nas notícias em tempo real e no contato ininterrupto; o espanto ocorre apenas se esses não são possíveis.

Embora os jovens dessa geração recebam muitas críticas pelo tempo despendido na rede, Tapscott (2010) defende que houve apenas uma mudança do meio de comunicação. Estima-se que os baby boomers assistiam a uma média de 22,4 horas de televisão semanais - com a televisão, sem diálogo ou interação, a pessoa se dispõe a receber de forma passiva tudo que lhe é oferecido. A nova geração usa a TV por menos tempo, apenas como pano de fundo, enquanto realiza outras tarefas, inclusive acessar a Internet. Têm grande possibilidade de interação com o novo meio, podem até gerar conteúdo, e não aceitam passivamente tudo o que lhes oferecem. Para Tapscott (2010, p. 30), “a 
geração Internet é a antítese da geração TV. A passagem de uma mídia difusora unidirecional para uma mídia interativa surtiu um efeito profundo na geração Internet”. As novas gerações passam de um antigo sistema, em que uma minoria falava para uma maioria passiva, para um novo sistema, em que, ao menos teoricamente, todos podem falar com todos.

Embora Tapscott tenha visão muito positiva da geração $\mathrm{Y}$ e suas implicações, outros autores mostram que é preciso ter cuidado na análise, pois muito do que parece ser uma solução pode se tornar um problema. Turkle (2011) apresenta preocupações quanto aos mais jovens, pois eles buscam nos computadores e dispositivos móveis a companhia que não têm pela ausência dos pais, e acabam por descobrir sua identidade imersos no ciberespaço, resultando em uma mudança na forma como se relacionam com eles mesmos e com os outros.

Analisando mais cuidadosamente os aspectos benéficos ou maléficos do uso dos novos meios, vê-se que cada indivíduo aprende a se comunicar, locomover e compreender o mundo e a si mesmo a partir das ferramentas a que tem acesso. A criança de hoje aprende a interagir com o mundo a partir das novas ferramentas: resolve problemas, se comunica e se compreende a partir da conexão virtual, daí a necessidade de estar sempre conectada. Sem um aparato com acesso à rede, depara com a necessidade de utilizar outras ferramentas que não aprendeu a manejar ou não desenvolveu a prática. Aprendeu a se comunicar por mensagens instantâneas, conhece a etiqueta do ambiente virtual, sabe que deve responder assim que visualizado e que esse período não pode ser longo. Sabe que deve digitar rápido, ser objetivo em suas declarações e sabe expressar ao máximo o sentimento que quer deixar transparecer por meio de gírias, expressões ou emoticons ${ }^{4}$. Fluente em seu meio, vê-se perdida ao ter de engatar conversa pessoalmente com outro indivíduo. Em um diálogo face a face, não pode começar a falar e voltar atrás para "editar" o modo como foi dito, e percebe que não sabe expressar um sorriso quando não quer rir, que não sabe olhar nos olhos e que não sabe se manter na conversa sem ter outra tarefa simultânea. O mesmo acontece com outras tarefas cotidianas, como localizar-se em um bairro ou cidade desconhecida, fazer amizade, escolher o programa da noite, entre outros.

Pode parecer absurda a comparação, mas seria o mesmo que convidar alguém nascido em meados do século XX a viver sem energia elétrica. A questão talvez seja que as tecnologias de hoje envolvem muito mais o relacionamento interpessoal. Assim como para nós seria difícil o armazenamento de alimentos sem um refrigerador ou um congelador, para um adolescente, comunicar-se se torna difícil sem sua ferramenta, seu gadget de acesso à rede, seu smartphone. Castells (2003, p. 7), pensando na eletricidade e na Internet, propõe que consideremos uma nova chamada Era da Informação:

[...] à medida que novas tecnologias de geração e distribuição de energia tornaram possível a fábrica e a grande corporação como os fundamentos organizacionais da sociedade industrial, a Internet passou a ser a base tecnológica para a forma organizacional da Era da Informação: a rede.

4. Sequência de caracteres tipográficos ou imagem que traduz ou quer transmitir um estado psicológico. 


\section{RESULTADOS, ANÁLISE E DISCUSSÕES}

Os questionários e os relatos sobre como é estar sem celular por indivíduos da geração $\mathrm{Z}$ evidenciaram maior familiaridade das gerações mais recentes com a rede. Os pesquisados, em sua maior parte, pertenciam à classe $\mathrm{C}$ e tinham ensino superior completo, à exceção de alguns das gerações mais recentes. Indivíduos da geração $\mathrm{Z}$ não tinham ainda, na ocasião da pesquisa, idade para um nível de escolaridade maior que ensino médio incompleto. A escolaridade, então, está intimamente relacionada à idade, mais do que com a renda. Entre os entrevistados, 96\% possuíam smartphones, sendo que alguns tinham dois ou mais aparelhos.

Quanto ao uso de smartphones em situações cotidianas, percebeu-se que é maior entre os mais novos, em situações multitarefas, resultado que vai ao encontro da afirmação de Tapscott (2010, p. 56), ao relatar que, "quando assistem à tevê, os integrantes da geração Internet a tratam como música de fundo enquanto buscam informações e batem papo com amigos na Internet ou ao telefone. A realização de várias tarefas é natural para essa geração".

Apesar de os baby boomers declararem alto índice de uso "durante o horário de expediente”, a natureza dessa utilização não é a mesma da de gerações mais novas e não se encaixa como atividade multitarefa, visto que, em outros momentos, baby boomers e indivíduos da geração $\mathrm{X}$ relataram utilizar o celular para o trabalho. Percebeu-se ainda que, entre os mais jovens, é comum o uso de smartphones em reuniões, aulas e palestras, fato já observado por outros pesquisadores e estudiosos, que relatam que as novas gerações têm maiores dificuldades em ambientes educacionais, chegando a chamá-la de geração DDA (com distúrbio de déficit de atenção). Tapscott (2010) concorda que eles parecem mais desatentos, mas levanta a possibilidade de estarem apenas entediados com o ritmo lento e o conteúdo da aula.

Na investigação sobre os hábitos, os pesquisados foram questionados quanto aos aplicativos que utilizam e respectivas frequências de uso, entre nunca e sempre. Os adolescentes da geração $\mathrm{Z}$ acessavam mais as redes sociais e o WhatsApp e utilizavam menos o e-mail e o SMS. Enquanto 83,33\% dos baby boomers e 83,87\% dos indivíduos da geração $\mathrm{X}$ sempre faziam ligações, apenas $56,07 \%$ da geração $\mathrm{Y}$ e menos da metade dos questionados da geração Z $(41,10 \%)$ o fazem.

Percebeu-se que as conversas passaram a ser, em sua minoria, faladas, e majoritariamente escritas, fenômeno explicado por Turkle (2011, p. 1), para quem isso se deve ao sentimento de maior controle da situação em conversas por mensagens de texto do que pessoalmente: "Nossa vida conectada permite nos esconder uns dos outros, mesmo quando estamos conectados uns com os outros. Preferimos escrever a falar". No mundo virtual, o indivíduo se constrói em alguém novo, editado.

Quanto ao e-mail, a pesquisa reforçou pensamentos de Tapscott (2010, p. 115), ao verificar que as novas gerações o utilizavam menos, preferindo aplicativos de conversação imediata. Tapscott analisa somente a geração Y, mas, pela pesquisa, a baixa utilização de $e$-mail também se verifica entre indivíduos da geração Z. O e-mail, pela baixa velocidade de comunicação, não atende às novas gerações.

O WhatsApp teve o maior índice de utilização entre todos os respondentes. Embora a baixa incidência de $e$-mail e a alta incidência 
de aplicativos de conversação imediata nas gerações mais recentes reforcem os pensamentos de Tapscott (2010, p. 29), o fato de o WhatsApp ter tido o maior índice de utilização entre todos os respondentes, inclusive pelas gerações mais antigas, contraria o pensamento do autor, que afirma que, "enquanto os adultos usavam a Internet para ver páginas da rede, os jovens que estudamos usavam a Internet para se comunicar com amigos”. Ressalte-se, porém, que o estudo de Tapscott não restringia o uso da Internet a smartphones, diferentemente de nossa pesquisa, o que pode ter causado a diferença de resultados.

Verificou-se ainda o possível encolhimento no uso do smartphone para realizar ligações entre as gerações mais novas. Enquanto para os baby boomers e os da geração X a ligação era a função mais utilizada, para a geração $Y$ estava em terceiro lugar, e para a geração Z, em quarto. Para as gerações $\mathrm{Y}$ e Z $\mathrm{Z}$, a função essencial do celular é o acesso à rede.

Questionados se seu celular é bloqueado por senha, a maioria dos pesquisados respondeu que sim. Os maiores índices de bloqueio estavam na geração Z: seus componentes parecem ter uma relação mais pessoal com o aparelho, que, possivelmente, guarda muito de sua intimidade.

Os pesquisados foram questionados também se já haviam perdido o celular, visando gerar um filtro para outra pergunta, sobre o tempo que demoraram para perceber o fato. Dos 281 questionados, 189 responderam que já haviam perdido. A maioria relatou ter demorado até 15 minutos para perceber a falta do aparelho, o que pode indicar a frequência com que buscam o celular para realizar alguma atividade. Se o aparelho fosse usado de forma mais esporádica, levariam mais tempo para sentir sua falta.

Os questionados foram solicitados a marcar as opções que descrevem como se sentiriam se fossem impedidos de utilizar ou portar o celular. Os das gerações baby boomer e X responderam que se sentiriam livres ou que não sentiriam nada relacionado ao fato. Todas as gerações alegaram que se sentiriam desatualizadas: estar "por fora" das novidades parecia, então, ser o que mais incomodava, caso lhes faltasse o smartphone. As gerações $\mathrm{X}$, Y e Z relataram também que ficariam impacientes sem o aparelho (um dos sintomas da chamada nomofobia), com maior proporção entre indivíduos da geração $\mathrm{Z}$, que talvez, por isso, sejam os mais dependentes. Diferentemente das gerações baby boomer e X, entrevistados das gerações $\mathrm{Y}$ e $\mathrm{Z}$ afirmaram que se sentiriam expostos, como se estivessem nus, achado que parece reforçar o pensamento de Turkle (2011), de que o ciberespaço seria o ambiente seguro para os mais jovens, onde se sentem no controle das situações e das pessoas. Sem seus smartphones, suas verdadeiras identidades ficam expostas a todos, ou seja, eles perdem a capacidade de se editar.

Uma observação interessante também apareceu no campo de respostas abertas, denominado "Outro": um participante relatou que se sentiria sem vida. Com a simultaneidade dos mundos carnal e alternativo, nossas vidas on-line e off-line passam a ser uma só. Assim, perder o acesso para a vida alternativa seria considerado como perder a vida, conforme explicado por Turkle (2011).

Ao fim do questionário, os pesquisados foram solicitados a completar a frase "Meu celular é um...”, sem possibilidade de marcar mais de uma opção ou escrever respostas abertas. Os baby boomers consideram o celular apenas como item essencial, sem maiores significações, principalmente pelo fato de estar intimamente ligado ao trabalho. 
A geração X afirmou que o celular é um "mal necessário”, “amigo" e "aparelho". "Aparelho" tem conotação bem impessoal, assim como "item", e dispensa o adjetivo "necessário", ou seja, a relação com o dispositivo móvel seria a de homem com objeto, possivelmente dispensável. O ato de optar por "mal necessário" deixa transparecer que o indivíduo sabe que o celular atrapalha em certos momentos, mas que mesmo assim precisa dele. A opção “amigo”, que aparece em menor representatividade para essa geração, já traz algo pessoal, entendendo o objeto a partir de adjetivos próprios de organismos vivos, o que parece estar de acordo com Turkle (2011) quando relata a relação de amizade de uma entrevistada com seu celular, que pega o aparelho para falar com amigos, confunde-se e declara que "pega seu amigo".

A geração Y acrescenta as significações "cúmplice” e "companheiro" ao gadget, sendo que ambas remetem a uma visão ainda mais pessoal dos smartphones. A escolha por "companheiro" indica que o aparato acompanha o indivíduo em grande parte do tempo, agregando à personificação do celular a necessidade de mantê-lo por perto. Cúmplice é aquele com quem se pode contar até mesmo para realizar um delito, ou que está presente em todos os momentos, inclusive flagrando situações comprometedoras e encobrindo pistas.

Os respondentes da geração $\mathrm{Z}$ foram os únicos que escolheram todas as opções para descrever o celular, visto até como "confidente", o que pressupõe que há confiança no smartphone, levando-o a mais um grau de personificação.

Além dos questionários aplicados, solicitou-se a dois participantes da geração Z, que ficaram temporariamente sem seus smartphones, que realizassem um breve relato sobre a experiência. Embora não se possa generalizar, pois não há representação do grupo, é possível encontrar dados que dialogam com informações levantadas pelos questionários e outros assuntos já explanados.

\section{Relato 1 - Sexo masculino, 18 anos}

Meu nome é Lucas, tenho 18 anos e hoje faz exatos 21 dias desde que roubaram meu celular, mas, para mim, parece que já tem mais de meses. Sabe aquela sensação de que está esquecendo algo quando sai de casa? Aquele desespero momentâneo de quando se apalpa os bolsos e percebe que seu celular não está lá? Essa sensação se tornou diária e rotineira para mim. Meu telefone celular era mais do que apenas um equipamento eletrônico, era minha porta de acesso para o mundo à minha volta, eu enxergava o mundo através de uma tela de cinco polegadas. Meu celular me deixava conectado, preparado para o que eu precisasse: uma mensagem que eu precisasse enviar, uma anotação que eu precisasse fazer, um texto que eu precisasse ler, um termo que eu precisasse pesquisar... estava tudo logo ali no meu bolso. No dia do roubo, nos primeiros minutos sem celular, o agente de polícia da delegacia me perguntou que horas havia sido o assalto, e eu, instintivamente, levei a mão ao bolso procurando o celular. E essa foi só a primeira de muitas vezes que isso aconteceu. A falta de celular me deixa com uma sensação de lentidão, como se eu tivesse perdido a praticidade de fazer coisas simples, como checar a previsão do tempo (e, sim, eu fazia isso com grande frequência). Ainda tem o fato de ter que esperar até chegar em casa para verificar a caixa de 
entrada do meu e-mail e ver que muitos deles já não precisam ser respondidos por já ter passado da hora. Não poder mais tirar uma foto a qualquer momento também me faz falta. Alguns dias atrás, vi um livro na vitrine de uma livraria e quis mostrar para um amigo meu, mas eu não podia simplesmente tirar uma foto e enviar para ele, não mais. Essas são apenas algumas das várias situações em que a falta de celular me incomodou, em meio a uma necessidade intensa e sensação de solidão.

\section{Relato 2 - Sexo feminino, 16 anos.}

Primeiramente, para começar a fazer este relato de um fim de semana sem meu celular, pensei em escrever nas notas do meu celular, até lembrar que estava sem ele. Decidi fazer no tablet para acelerar o processo. Logo quando "perdi" meu celular, fiquei, eu mesma, meio perdida. Sem saber o que fazer e sem saber como me comunicaria com as pessoas. Em um segundo momento, me senti perdida em relação às horas, pois não costumo usar relógio e sempre consultei meu celular para saber as horas. Com o passar do dia, deparei com outros problemas: quase fui em um evento desmarcado por WhatsApp; não pude ajudar a motorista do carro a achar nosso destino, pois não sabíamos onde ficava e não tinha aceso aos aplicativos de localização; precisava de uma informação específica de um site quando estava fora de casa e com um celular simples (sem ser smartphone e sem acesso à Internet) e não pude tê-la; não foi legal ter me arrumado bem para sair sem poder tirar uma foto (fiquei muito chateada); meus amigos ficaram preocupados comigo, pois não respondi as suas mensagens.

Em ambos os relatos, quando solicitados a realizar alguma ação (escrever o diário e verificar a hora do furto), o primeiro ímpeto foi buscar o celular. Há uma ação espontânea, quase automática, de utilizá-lo, visto que, somente após terem indicado um início de ação, se lembraram de que o dispositivo não estava disponível. A ação parece, portanto, um comportamento de reflexo. Outro ponto em comum é que ambos relatam, de alguma forma, a relação entre tecnologia e velocidade. Segundo o indivíduo do sexo masculino, "a falta de celular me deixa com uma sensação de lentidão", e o indivíduo do sexo feminino, ao perceber que estava sem celular, decidiu registrar tudo no tablet (outro dispositivo móvel digital) "para acelerar o processo".

Tapscott (2010, p. 50) apresenta a velocidade como uma das oito normas da geração Internet: "num mundo em que a velocidade caracteriza o fluxo de informações entre vastas redes de pessoas, a comunicação com amigos, colegas e superiores acontece mais rápido do que nunca”. Embora o autor apresente a velocidade como característica típica da geração $\mathrm{Y}$, vemos, pelos relatos desta pesquisa, que isso também vale para a geração Z. Para os mais jovens, a velocidade parece ser ainda mais importante do que para a geração anterior, visto que 0 mundo apresenta informações cada vez mais aceleradas e imediatas.

Nos dois relatos, os indivíduos reclamam da comunicação e enfatizam a impossibilidade de enviar ou receber mensagens. Não se verifica em nenhum momento que se sentiram incomodados por não 
poderem ligar, reforçando o que foi encontrado nos questionários e o que já vem sendo tratado na literatura: preferem escrever a falar (Turkle, 2011).

Outro ponto observado é que, para os dois indivíduos, o acesso à rede somente a partir de suas casas não é satisfatório. Eles buscam acessar o mundo representativo em seus deslocamentos. Um deles relata que, quando retorna para casa e acessa seus e-mails, muitas demandas já se tornaram ultrapassadas; outro, que quase foi em um evento desmarcado pelo aplicativo de conversação imediata e que precisou acessar uma informação na rede quando estava na rua. Percebe-se que o contexto em que estão inseridos exige que ajam com velocidade e que estejam todo o tempo conectados, pois as informações mudam rapidamente; isso poderia explicar a grande sensação de desatualização relatada quando perguntados como se sentiriam se não pudessem portar ou utilizar o celular.

Por último, verificamos que ambos relatam uma sensação de desorientação. Um reporta desespero instantâneo ao perceber que está sem o celular; outro que, sem o celular, a praticidade seria comprometida. Os relatos mostram como o dia a dia desses indivíduos está intimamente ligado a celulares, recorrendo a eles nas mais variadas situações. O mesmo pôde ser percebido pelos questionários.

\section{CONCLUSÕES E RECOMENDAÇÕES}

A configuração do mundo atual exige do ser humano cada vez mais eficiência e velocidade. Para atender a essas expectativas, são necessários o acesso e a utilização da tecnologia. A dependência em relação aos novos aparatos seria a consequência do novo modelo imediatista informacional e social.

Os que nasceram nesse novo cenário têm a necessidade de ser mais velozes e eficientes do que os que construíram sua personalidade e aprenderam a ver o mundo em outro contexto. Os mais jovens entendem o mundo a partir do virtual, e a si mesmos a partir de suas representações na rede. Assim como alguém com alguma deficiência visual precisa do auxílio das mãos para, pelo tato, entender o ambiente em que está inserido, o jovem parece precisar do virtual para "ver" o mundo.

Conclui-se que os smartphones são parte expressiva da rotina da grande maioria dos entrevistados, principalmente de indivíduos das gerações Y e Z. Ao compará-las, percebemos que, para a geração Z, o celular possui novas significações e, além de ser essencial, é parte dela. Essa geração tende a ser mais dependente dos dispositivos móveis digitais do que a geração Y, embora seja sutil a diferença encontrada entre ambas na pesquisa.

A geração Z, mais do que a geração Internet, sente necessidade quase ininterrupta de acesso ao mundo representativo. Ela evita, ainda mais, os contatos pessoais via ligação de voz e encontram, na possibilidade de edição do mundo virtual, a proteção de não precisar mostrar quem realmente é. Seus componentes são os que mais se sentem expostos sem os dispositivos móveis e os que mais apresentam sintomas de abstinência sem o celular, como impaciência e irritabilidade. Além disso, levam a Internet da geração anterior para todos os lugares e momentos; Internet e tempo são ferramentas essenciais. O zapear, típico dessa geração, não se daria somente com a troca de foco entre inúmeras tarefas, mas entre 
os mundos alternativo e carnal, se é que se pode falar em zapear, visto que ocorre, hoje, mais uma sobreposição do que uma troca.

Os dispositivos móveis digitais possibilitam essa imersão na rede de forma ininterrupta, e, para as gerações mais novas, a conexão a todo tempo passa a ser não somente possível, como obrigatória. Ouvimos recentemente de uma adolescente uma frase que definiria o exposto e resumiria as implicações dessa imersão atual: "Hoje a gente já não fala mais ‘oi' quando chega na casa de alguém, fala ‘qual é a senha do wifi?”. Para a geração Z, a interação no mundo virtual vem antes da interação no mundo carnal.

Este trabalho pode também ser resumido em outra frase, que apareceu em um dos relatos de indivíduos da geração $\mathrm{Z}$, que indica o nível de dependência observado nos questionários, dialoga com os pensamentos dos autores estudados e alerta para a aparente redução da complexidade do nosso ser: "Quando perdi meu celular, fiquei totalmente perdida".

O relacionamento dos indivíduos com os dispositivos móveis digitais é um assunto vasto, rico e relativamente recente, carecendo de estudos com os mais variados enfoques. Este trabalho recorta o objeto da pesquisa para a relação entre as duas gerações mais recentes e o smartphone, como representante dos dispositivos móveis digitais, porém as outras gerações também apresentam relação com o mundo representativo - estas, pelo que verificamos, estão mais conectadas do que imaginamos. Seria interessante analisar como as gerações baby boomer e X relacionam-se com essas novas formas de imersão no ciberespaço. Outro ponto que poderia ser estudado é a diferença da relação com os telefones móveis mais simples e com os smartphones, para verificar se a comunicação móvel apenas por meio de ligações e mensagens de texto é hoje tão representativa ou se é necessária imersão na rede de forma móvel para que seja considerada essencial.

A verificação da dependência poderia ser ainda aprofundada a partir de outros métodos de pesquisa, como grupos focais e entrevistas em profundidade. Experimentos menos subjetivos também poderiam auxiliar na riqueza de dados, como a verificação das reações físicas de indivíduos quando separados de seus celulares.

\section{REFERÊNCIAS}

ABREU, C. N.; COSTA, M. L.; GÓES, D. S. Dependência de celular. In: ABREU, C. N.; EISENSTEIN, E.; ESTEFENON, S. G. B. (Orgs.). Vivendo esse mundo digital: impactos na saúde, na educação e nos comportamentos sociais. Porto Alegre: Artmed, 2013.

ANATEL. Brasil ultrapassa um celular por habitante. 2014. Disponível em: https://goo.gl/ a9YPJ0. Acesso em: 5 nov. 2014.

BERNARD, J. The cellular connection: a guide to cellular telephones. 4. ed. Londres: Quantum, 1990

CASTELLS, M. A galáxia internet: reflexões sobre a internet, os negócios e a sociedade. Rio de Janeiro: Jorge Zahar, 2003.

CLYNES, M. E.; KLINE, N. S. Cyborgs and space. Astronautics, set. 1960, p. 26-76.

ENGELMANN, D. C. O futuro da gestão de pessoas: como lidaremos com a geração Y?. 26 mar. 2007. Disponível em: https://goo.gl/EH6r1t. Acesso em: 9 jul. 2014.

LEMOS, A. Cibercultura: tecnologia e vida social na cultura contemporânea. 6. ed. Porto Alegre: Sulina, 2013.

LÉVY, P. Cibercultura. 3. ed. São Paulo: Editora 34, 2010 
MALAFAIA, G. S. Gestão estratégica de pessoas em ambientes multigeracionais. In: CONGRESSO NACIONAL DE EXCELÊNCIA EM GESTÃO, 7., Rio de Janeiro e Niterói, 2011. Anais eletrônicos. Rio de Janeiro e Niterói: UFF, 2011. Disponível em: http://bit.ly/2eOsUM8. Acesso em: 20 out. 2016.

MCLUHAN, M. Os meios de comunicação como extensões do homem: understanding media. 18. ed. São Paulo: Cultrix, 2012.

ROCHA, E.; BARROS, C. Dimensões culturais do marketing: teoria antropológica, etnografia e comportamento do consumidor. RAE - Revista de Administração de Empresas, v. 46, n. 4, out.-dez. 2006.

ROTHBERG, M. B. et al. Phantom vibration syndrome among medical staff: a cross sectional survey. BMJ, n. 341, dez 2010. Disponível em: https://goo.gl/K3Rz8L. Acesso em: 10 nov. 2014.

SANTAELLA, L. Revisitando o corpo na era da mobilidade. In: LEMOS, A; JOSGRILBERG, F. (Org.). Comunicação e mobilidade: aspectos socioculturais das tecnologias móveis da comunicação no Brasil. Salvador: EDUFBA, 2009.

. Pós-humano: por quê?. Revista USP, São Paulo, n. 74, p. 126-137, jun./ago. 2007. Disponível em: https://goo.gl/5YtCze. Acesso em: 10 out. 2016.

2004. . Navegar no ciberespaço: o perfil cognitivo do leitor imersivo. São Paulo: Paulus, 2001.

. Comunicação e pesquisa: projetos para mestrado e doutorado. São Paulo: Hacker,

SIBILIA, P. O show do eu: a intimidade como espetáculo. Rio de Janeiro: Nova Fronteira, 2008.

TAPSCOTT, D. A hora da geração digital: como jovens que cresceram usando a internet estão mudando tudo, das empresas aos governos. Rio de Janeiro: Agir Negócios, 2010.

TELECO. Estatísticas de celulares no Brasil. s/d. Disponível em: https://goo.gl/xK34nD. Acesso em: 7 jul. 2014.

TURKLE, Sherry. Alone together. Nova York: Basic Books, 2011.

WILLIAMS, C. "Phantom" cell phone sensations: mind over matter. ABC News, 17 set. 2007. Disponivel em: http://abcn.ws/2eHdw8D. Acesso em: 7 jul. 2014. 